\title{
Weed Management in New Zealand Pastures
}

\author{
Hossein Ghanizadeh *(1) and Kerry C. Harrington (1) \\ School of Agriculture and Environment, Massey University, PB 11-222, Palmerston North 4442, New Zealand \\ * Correspondence: H.Ghanizadeh@massey.ac.nz; Tel.: +64-6-951-9165
}

Received: 28 July 2019; Accepted: 9 August 2019; Published: 13 August 2019

\begin{abstract}
In New Zealand, pastoral farming for dairy and meat production is the major land use. As with any agricultural production system, weeds are a threat to efficient pasture production in New Zealand. In this review, we outline the problems caused by weeds in New Zealand pastures, and the management strategies being used to control them. There are currently 245 plant species from 40 plant families that are considered to be troublesome weeds in New Zealand pastures. The application of herbicides is an important approach to manage weeds in New Zealand pastures; however, a key to the success of these pastures is the use of clovers in combination with the grasses, so the challenge is to find herbicides that selectively control weeds without damaging these legumes. The use of spot spraying and weed wiping are often required to ensure selective control of some weed species in these pastures. Non-chemical agronomic approaches such as grazing management and using competitive pasture species often play a more important role than herbicides for weed management in many New Zealand pastures. Thus, integrated weed management using a combination of herbicides and good pasture management strategies leads to the most cost-effective and efficient control of pasture weeds in New Zealand.
\end{abstract}

Keywords: Integrated weed Management; New Zealand; pasture; perennial weeds; thistles; weed control

\section{Introduction}

It has been estimated that current world food production needs to increase by $70-100 \%$ in order to meet the world food demand in 2050 [1]. Livestock products such as milk and meat contribute greatly to the global consumption of protein and kilocalories [2]. Hence, increasing livestock production is considered necessary for the future world food demand [3]. New Zealand livestock production contributes to the global food supply, with dairy products accounting for $3 \%$ of total world production [4].

Weeds are unwanted plants and are regarded as one of the biotic impediments to world agricultural production [5]. If left uncontrolled, weeds not only influence the quantity (i.e., yield) of the desirable plants but also affect the quality of the crops [6]. Effective weed management measures have always been crucial for successful agricultural production. Before the advent of herbicides, the common methods of weed control included crop competition and physical removal of weeds such as by cultivation or hand-weeding [7]. However, since their advent, the application of herbicides has become the most popular method for weed control $[7,8]$.

In New Zealand, pastoral farming for dairy and meat production is the major land use, with most livestock production involving feeding animals outdoors on pastures throughout the year. Most pastures in New Zealand consist of a mixture of grasses and clovers [9]. While perennial ryegrass (Lolium perenne L.) is the most common grass species sown for permanent pasture, other species such as Festuca arundinacea Schreb. and Lolium multiflorum Lam. may also be used [9]. The most popular clover species sown in New Zealand pastures is white clover (Trifolium repens L.), although mixes with subterranean clover (Trifolium subterraneum L.) and red clover (Trifolium pretense L.) are also common $[9,10]$. As with any agricultural sector, weeds are a threat to pasture production in 
New Zealand as they reduce the quality and the quantity of the fodder produced for the animals. In New Zealand pastures, a plant is regarded as a weed if it is not sown from seeds [10]. In pastures, weeds can reduce pasture persistence, utilization and production [11], and these weeds can cost farmers millions of dollars per annum [12]. Therefore, pasture weeds in New Zealand need to be managed appropriately to reduce their economic impacts [13].

In this review, we outline common weeds that are threatening pastures in New Zealand and discuss different management practices that are being used to control them. The last review on weed management in New Zealand pastures was published more than a decade ago [14], so here we focus on recent developments. We discuss recent research that has been undertaken to improve weed management practices in New Zealand pastures, and outline other research that is needed to help improve weed management in New Zealand pastures.

\section{Common Weeds in New Zealand Pastures}

We list the plant species considered to be weeds for New Zealand pastures. This was done by listing species, from two New Zealand weed identification books [15,16], that were described as being found in pastures (Table 1). Those species considered worthy of inclusion in these books written by some of New Zealand's leading weed scientists were deemed important enough to include in Table 1. It does not include the arable cropping annuals often found in new pastures, but which disappear rapidly once pastures have been grazed several times.

Table 1. Common weeds in established New Zealand pastures. Species considered here as pastoral weeds are those with habitats defined as pasture or grassland by Popay et al. [15] and Champion et al. [16].

\begin{tabular}{|c|c|}
\hline Family & Species Botanical Name \\
\hline Amaranthaceae & Alternanthera philoxeroides (Mart.) Griseb \\
\hline \multirow[t]{2}{*}{ Apiaceae } & Conium maculatum L. \\
\hline & Oenanthe pimpinelloides L. \\
\hline Araceae & Arum italicum Mill. \\
\hline Araliaceae & Tetrapanax papyrifer (Hook.) K.Koch \\
\hline \multirow{27}{*}{ Asteraceae } & Achillea millefolium $\mathrm{L}$. \\
\hline & Anthemis cotula L. \\
\hline & Arctium lappa L. \\
\hline & Arctium minus (Hill) Bernh. \\
\hline & Arctotheca calendula (L.) Levyns \\
\hline & Aster subulatus (Michx.) G.L.Nesom \\
\hline & Bellis perennis L. \\
\hline & Carduus acanthoides L. \\
\hline & Carduus nutans L. \\
\hline & Carduus pycnocephalus L. \\
\hline & Carduus tenuiflorus Curtis \\
\hline & Carthamus lanatus L. \\
\hline & Centaurea calcitrapa L. \\
\hline & Centaurea melitensis L. \\
\hline & Centaurea nigra L. \\
\hline & Centaurea solstitialis L. \\
\hline & Cirsium arvense (L.) Scop. \\
\hline & Cirsium palustre (L.) Scop. \\
\hline & Cirsium vulgare (Savi) Ten. \\
\hline & Conyza sumatrensis (Retz.) E. Walker \\
\hline & Cotula australis (Sieber ex Spreng.) Hook. \\
\hline & Crepis capillaris (L.) Wallr. \\
\hline & Crepis setosa Haller $\mathrm{f}$. \\
\hline & Crepis vesicaria $\mathrm{L}$. \\
\hline & Dittrichia graveolens (L.) Greuter \\
\hline & Erechtites valerianifolia (Link ex Spreng.) DC \\
\hline & Euchiton sphaericus (Willd.) Holub \\
\hline
\end{tabular}


Table 1. Cont.

\begin{tabular}{|c|c|}
\hline Family & Species Botanical Name \\
\hline & $\begin{array}{l}\text { Galinsoga parviflora Cav. } \\
\text { Gamochaeta calviceps (Fernald) Cabrera } \\
\text { Gamochaeta coarctata (Willd.) Kerguélen } \\
\text { Gamochaeta purpurea (L.) Cabrera } \\
\text { Gamochaeta simplicicaulis (Willd. ex Spreng.) Cabrera } \\
\text { Gamochaeta subfalcatum Cabrera } \\
\text { Helminthotheca echioides (L.) Holub } \\
\text { Hypochaeris glabra L. } \\
\text { Hypochaeris radicata L. } \\
\text { Jacobaea vulgaris Gaertn. } \\
\text { Leontodon autumnalis (L.) Moench } \\
\text { Leontondon taraxacoides (Vill.) Mérat } \\
\text { Leucanthemum vulgare Lam. } \\
\text { Onopordum acanthium L. } \\
\text { Ozothamnus leptophyllus } \\
\text { Pilosella aurantiaca (L.) F.W.Schultz \& Sch.Bip. } \\
\text { Pilosella officinarum Vaill. } \\
\text { Pilosella piloselloides subsp. Praealta (Gochnat) S.Bräut. \& Greuter } \\
\text { Pseudognaphalium luteoalbum (L.) Rchb. } \\
\text { Senecio bipinnatisectus } \\
\text { Senecio glastifolius L. } \\
\text { Senecio sylvaticus L. } \\
\text { Silybum marianum (L.) Gaertn. } \\
\text { Sonchus asper (L.) Hill } \\
\text { Sonchus oleraceus L. } \\
\text { Taraxacum officinale (L.) Weber ex F.H. Wigg } \\
\text { Tragopogon porrifolius L. }\end{array}$ \\
\hline Asteraceae & Xanthium spinosum $\mathrm{L}$. \\
\hline Berberidaceae & $\begin{array}{l}\text { Berberis darwinii Hook. } \\
\text { Berberis glaucocarpa }\end{array}$ \\
\hline Boraginaceae & $\begin{array}{l}\text { Echium vulgare L. } \\
\text { Myosotis discolor Pers. }\end{array}$ \\
\hline Brassicaceae & $\begin{array}{l}\text { Lepidium didymum L. } \\
\text { Rorippa sylvestris (L.) Besser } \\
\text { Sisymbrium officinale (L.) Scop. }\end{array}$ \\
\hline Caryophyllaceae & $\begin{array}{l}\text { Arenaria serpyllifolia } \mathrm{L} \text {. } \\
\text { Cerastium arvense L. } \\
\text { Cerastium fontanum Baumg. } \\
\text { Cerastium glomeratum Thuill. } \\
\text { Polycarpon tetraphyllum L. } \\
\text { Silene gallica L. } \\
\text { Silene latifolia Poir. } \\
\text { Stellaria media (L.) Vill. }\end{array}$ \\
\hline Convolvulaceae & $\begin{array}{l}\text { Calystegia silvatica (Kit.) Griseb. } \\
\text { Dichondra repens J.R.Forst. \& G.Forst. }\end{array}$ \\
\hline Cyperaceae & $\begin{array}{l}\text { Carex comans Berggr. } \\
\text { Carex divulsa Stokes } \\
\text { Carex geminate Schkuhr } \\
\text { Carex inversa R.Br. } \\
\text { Carex longebrachiata Boeckeler } \\
\text { Carex ovalis L. } \\
\text { Carex vulpinoidea Michx. } \\
\text { Cyperus brevifolius (Rottb.) Hassk. } \\
\text { Cyperus congestus Vahl. } \\
\text { Cyperus Eragrostis Lam. } \\
\text { Cyperus ustulatus A.Rich. }\end{array}$ \\
\hline
\end{tabular}


Table 1. Cont.

\begin{tabular}{|c|c|}
\hline Family & Species Botanical Name \\
\hline Dennstaedtiaceae & $\begin{array}{l}\text { Paesia scaberula (A.Rich.) Kuhn } \\
\text { Pteridium esculentum (G.Forst.) Cockayne }\end{array}$ \\
\hline Ericaceae & $\begin{array}{l}\text { Calluna vulgaris (L.) Hull } \\
\text { Erica cinerea L. } \\
\text { Erica lusitanica Rudolphi }\end{array}$ \\
\hline Fabaceae & $\begin{array}{l}\text { Acacia mearnsii De Wild. } \\
\text { Cytisus scoparius (L.) Link } \\
\text { Galega officinalis L. } \\
\text { Genista monspessulana (L.) O.Bolós \& Vigo } \\
\text { Medicago Arabica (L.) Huds. } \\
\text { Medicago lupulina L. } \\
\text { Psoralea pinnata L. } \\
\text { Trifolium arvense L. } \\
\text { Ulex europaeus L. }\end{array}$ \\
\hline Gentianaceae & Centaurium erythraea Rafn \\
\hline Geraniaceae & $\begin{array}{l}\text { Erodium cicutarium (L.) L'Hér. ex Aiton } \\
\text { Erodium moschatum (L.) L’Hér. } \\
\text { Geranium molle L. }\end{array}$ \\
\hline Hypericaceae & $\begin{array}{l}\text { Hypericum androsaemum } \mathrm{L} . \\
\text { Hypericum perforatum } \mathrm{L} .\end{array}$ \\
\hline Iridaceae & $\begin{array}{l}\text { Romulea rosea } \\
\text { Sisyrinchium iridifolium Cav. }\end{array}$ \\
\hline Juncaceae & $\begin{array}{l}\text { Juncus articulates L. } \\
\text { Juncus australis Hook.f. } \\
\text { Juncus bufonius L. } \\
\text { Juncus edgariae L.A.S.Johnson \& K.L.Wilson } \\
\text { Juncus effuses L. } \\
\text { Juncus lomatophyllus Sprengel } \\
\text { Juncus pallidus R.Br. } \\
\text { Juncus sarophorus L.A.S.Johnson } \\
\text { Juncus tenuis Willd. } \\
\text { Juncus usitatus L.A.S.Johnson } \\
\text { Luzula congesta } \\
\text { Luzula multiflora (Ehrh.) Lej. }\end{array}$ \\
\hline Lamiaceae & $\begin{array}{l}\text { Lamium purpureum } \mathrm{L} . \\
\text { Lycopus europaeus } \mathrm{L} . \\
\text { Marrubium vulgare } \mathrm{L} . \\
\text { Mentha pulegium } \mathrm{L} . \\
\text { Origanum vulgare } \mathrm{L} . \\
\text { Prunella vulgaris } \mathrm{L} . \\
\text { Salvia verbenaca } \mathrm{L} .\end{array}$ \\
\hline Linaceae & $\begin{array}{l}\text { Linum bienne Mill. } \\
\text { Linum trigynum L. }\end{array}$ \\
\hline Malvaceae & $\begin{array}{l}\text { Malva parviflora } \mathrm{L} . \\
\text { Malva neglecta Wallr. } \\
\text { Malva nicaeenis All. } \\
\text { Malva sylvestris L. } \\
\text { Modiola caroliniana (L.) G.Don } \\
\text { Sida rhombifolia L. }\end{array}$ \\
\hline Myrtaceae & $\begin{array}{l}\text { Leptospermum scoparium J.R.Forst. \& G.Forst. } \\
\text { Kunzea ericoides (A.Rich.) Joy Thomps. }\end{array}$ \\
\hline Orobanchaceae & $\begin{array}{l}\text { Orobanche minor James Edward Smith } \\
\text { Parentucellia viscosa (L.) Caruel }\end{array}$ \\
\hline Oxalidaceae & $\begin{array}{l}\text { Oxalis corniculata } \mathrm{L} . \\
\text { Oxalis exilis A.Cunn. }\end{array}$ \\
\hline Phytolaccaceae & Phytolacca octandra L. \\
\hline
\end{tabular}


Table 1. Cont.

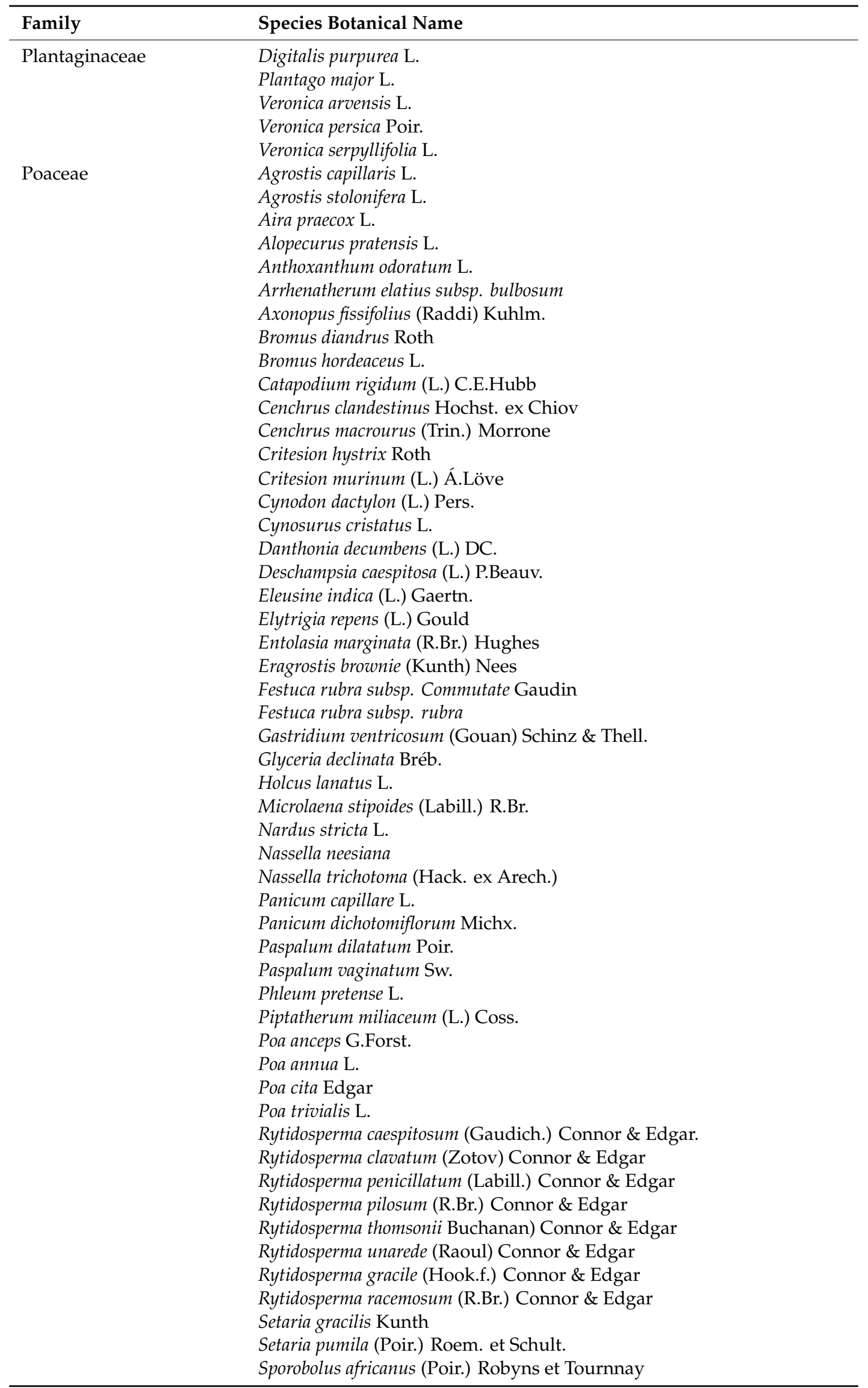


Table 1. Cont.

\begin{tabular}{|c|c|}
\hline Family & Species Botanical Name \\
\hline & Stenotaphrum secundatum (Walter) Kuntze \\
\hline & Vulpia bromoides (L.) Gray \\
\hline Poaceae & Vulpia myuros (L.) C.C.Gmel. \\
\hline Polemoniaceae & Navarretia squarrosa (Eschsch.) Hook. et Arn. \\
\hline \multirow[t]{8}{*}{ Polygonaceae } & Emex australis Steinh. \\
\hline & Persicaria hydropiper (L.) Delabre \\
\hline & Rumex acetosella L. \\
\hline & Rumex brownie Campd. \\
\hline & Rumex conglomeratus Murray \\
\hline & Rumex crispus L. \\
\hline & Rumex obtusifolius L. \\
\hline & Rumex pulcher $\mathrm{L}$. \\
\hline Portulacaceae & Montia fontana subsp. chondrosperma \\
\hline \multirow[t]{2}{*}{ Proteaceae } & Hakea salicifolia (Vent.) B.L.Burtt \\
\hline & Hakea sericea Schrad. \& J.C.Wendl \\
\hline \multirow[t]{9}{*}{ Ranunculaceae } & Ranunculus acris L. \\
\hline & Ranunculus bulbosus L. \\
\hline & Ranunculus ficaria Huds. \\
\hline & Ranunculus flammula $\mathrm{L}$. \\
\hline & Ranunculus muricatus L. \\
\hline & Ranunculus parviflorus L. \\
\hline & Ranunculus repens L. \\
\hline & Ranunculus sardous Crantz \\
\hline & Ranunculus sceleratus L. \\
\hline Resedaceae & Reseda luteola $\mathrm{L}$. \\
\hline Rhamnaceae & Discaria toumatou Raoul \\
\hline \multirow[t]{8}{*}{ Rosaceae } & Acaena agnipila Gand. \\
\hline & Acaena anserinifolia (J.R.Forst. \& G.Forst.) J.B.Armstr. \\
\hline & Acaena novae-zelandiae Kirk \\
\hline & Aphanes arvensis $\mathrm{L}$. \\
\hline & Aphanes inexpectata \\
\hline & Crataegus monogyna Jacq. \\
\hline & Rosa rubiginosa L. \\
\hline & Rubus fruticosus L. \\
\hline Rubiaceae & Sherardia arvensis L. \\
\hline Scrophulariaceae & Verbascum thapsus L. \\
\hline \multirow[t]{6}{*}{ Solanaceae } & Datura stramonium L. \\
\hline & Lycium ferocissimum Miers \\
\hline & Solanum linnaeanum Hepper \& P.-M.L.Jaeger \\
\hline & Solanum marginatum L.f. \\
\hline & Solanum mauritianum Scop. \\
\hline & Solanum nigrum L. \\
\hline Urticaceae & Urtica dioica $\mathrm{L}$. \\
\hline & Urtica urens L. \\
\hline
\end{tabular}

In total, this gave us a list of 245 species from 40 different families. Nearly $47 \%$ of the 219 plant species belong to the Poaceae (59 species) and Asteraceae (42 species) families. Bourdôt et al. [14] reviewed and ranked the most important weeds in pastures based both on the numbers of manuscripts published on individual weeds and farmer surveys. The top ten most important weeds when considering published papers were Ulex europaeus L., Critesion spp., Jacobaea vulgaris Gaertn, Carduus nutans L., Cirsium arvense (L.) Scop., Ranunculus acris L., Rubus fruticosus L., Cytisus scoparius (L.) Link, Achillea millefolium L. and Juncus sarophorus L.A.S.Johnson. According to the farmer surveys, the most important weed species were considered to be Critesion spp., Ulex europaeus, Carduus nutans, Cytisus scoparius, Rosa rubiginosa, Discaria toumatou Raoul, Pilosella spp. and Coriaria spp. [14]. Bourdôt et al. [14] stated that the lack of agreement between research studies and farmers in rankings of importance 
of pastoral weeds was due to a lack of unbiased information about the impact and cost of weeds in pastures. The most recent estimate for annual cost of pastoral weeds showed that Cirsium arvense causes the most production losses in New Zealand pastures followed by Setaria pumila (Poir.) Roem. et Schult., Ranunculus acris, Ulex europaeus, Nassella trichotoma (Hack. ex Arech.), Rubus fruticosus, Cytisus scoparius, Rosa rubiginosa, Pilosella spp. and Nassella neesiana [17].

\section{Problems Caused by Weeds in Pasture}

\subsection{Competition}

In pastures, weeds compete with pasture grasses and legumes for resources such as water, light and mineral nutrients [18]. The competitive interaction between weeds and pasture species can lead to a reduction in the survivorship, growth and reproduction of the pasture species if dominated by the weed species [11]. Weed species in pastures can replace the pasture plants through competition [12]. Many studies have demonstrated detrimental competitive effects of weeds such as Cirsium vulgare (Savi) Ten. [19], Carduus nutans [20], Cirsium arvense [21], and Setaria pumila [22] on forage growth and quality.

\subsection{Allelopathic Plants}

Allelopathy can occur as part of interference responses between plants [23], though allelopathy is generally considered to be less important in plant interference than competition [24]. Wardle [25] has reviewed the allelopathic potential of weeds in the New Zealand pasture ecosystem and found that some of these species release chemicals into their surrounding environment, potentially causing detrimental effects on the production of desirable pasture species [26]. For instance, Jacobaea vulgaris was shown to have an allelopathic influence on perennial ryegrass growth [27]. Wardle et al. [28] also noted that Carduus nutans had a detrimental effect on the growth of six grass species and four legume species, with the most allelopathic impact of the weed recorded at its rosette stage. Smith [26] also reported some allelopathic impacts of Anthemis cotula L. on the seedlings of Medicago sativa L. and Lolium multiflorum. Allelopathic compounds have also been found in some other pasture weed species include Cirsium arvense, Cyperus spp., and Elytrigia repens (L.) Gould [29]. However, Wardle [25] concluded that most of the allelopathic studies involving New Zealand pastoral weeds were conducted under laboratory conditions, and the relative importance of allelopathy compared with competition under field conditions remains unclear.

\subsection{Effect of Weeds on Livestock Health}

In pastures, some weeds such as Ranunculus acris [30] can cause acute or chronic poisoning when consumed by livestock. Other weed species such as Jacobaea vulgaris and Conium maculatum L. contain toxic alkaloids that can cause jaundice or birth defects in pregnant animals, respectively, or even death when consumed by cattle [31]. Some weeds such as Nassella trichotoma cause physical injury to livestock leading to secondary viral infections through punctures in the mouth [32].

\subsection{The Impact of Weeds on Product Quality}

Weeds can reduce the quality and value of livestock products. For example, seed heads from Critesion spp. and thistles such as Cirsium vulgare can reduce the value of wool by contaminating it [32]. Weed species such as Anthemis cotula and Arctotheca calendula (L.) Levyns can taint milk or meat flavor when consumed by stock [32-34].

\subsection{Avoidance and Reduced Pasture Utilization}

Weeds in pastures can prevent livestock from accessing the pasture immediately surrounding the weed [29]. Thistle species such as Cirsium arvense with their prickly leaves [35] and poisonous plants such as Ranunculus acris are generally avoided by livestock in pastures [30]. Also, some scrub weeds 
such as Ulex europaeus and Rubus fruticosus make it difficult for stock to graze the forage growing under the plants, thus reducing pasture utilization. Some weedy plants such as Rumex spp. and Juncus spp. are of low nutritive value and are unpalatable compared with desirable pasture species [36], and their presence in pastures occupies space that could have been used to grow more nutritious species [32]. Unless a reasonable grazing pressure is maintained, the rejection of certain less preferred weed species by livestock can promote their dominance in pastures [37].

\section{Chemical Control and Herbicide Resistance}

In pastures, herbicides are important for maintaining production. Soon after the initial discovery of the first selective herbicides, MCPA (2-methyl-4-chlorophenoxyacetic acid) and 2,4-D (2,4-dichlorophenoxyacetic acid), there was a rapid increase in their use in New Zealand [14]. The challenge has been to find herbicides that selectively control weeds without damaging the pasture species, as New Zealand pastures are based on mixtures of grasses and broadleaf species such as legumes [38]. Hence, herbicides are often applied using methods such as spot spraying [39] and weed wiping $[40,41]$ in order to apply non-selective herbicides for selective control of weeds in pastures.

\section{Herbicides Used in New Zealand Pastures}

\subsubsection{Auxinic Herbicides}

Phenoxy herbicides such as MCPA and 2,4-D selectively control many broad-leaved plants without harming grasses [42]. These two herbicides are the most commonly used herbicides in New Zealand pastures for boom spraying because they are cheaper compared with other alternatives [37,38]. Although MCPA and 2,4-D are chemically very similar, their effectiveness against certain species differs. For instance, Thomson and Saunders [42] showed that 2,4-D compared to MCPA provided better control of Jacobaea vulgaris though MCPA is more effective against thistles [43] and Ranunculus acris [44]. However, farmers usually prefer to use 2,4-D since this herbicide is cheaper than MCPA [45].

The main problem with MCPA and 2,4-D is that they cause the suppression of clover [42] and are not effective in controlling very mature weeds and perennials [46]. There are other phenoxy herbicides, such as MCPB (4-(4-chloro-2-methylphenoxy)butanoic acid) and 2,4-DB (4-(2,4-dichlorophenoxy)butyric acid), that do not cause any damage to either pasture grasses or clovers [43]. This is because pasture legumes do not convert 2,4-DB and MCPB from their non-toxic forms to the toxic molecules of 2,4-D and MCPA respectively, hence are generally tolerant of these herbicides [33]. However, MCPB and 2,4-DB are not used as extensively as other phenoxy herbicides because of their relatively higher cost and lower efficacy against mature weeds than MCPA and 2,4-D [43].

In New Zealand pastures, a benzoic acid group herbicide, dicamba, and pyridine group herbicides, clopyralid, aminopyralid, picloram and triclopyr, are the other auxinic herbicides that are sprayed in mixtures to control a broad spectrum of weeds, but they are toxic to clover [14,47,48]. Although these herbicides are more readily translocated within the plant than MCPA or 2,4-D, they have a persistent soil residual activity which will preclude re-planting of clover for months [14]. In New Zealand pastures, these herbicides are commonly used for spot spraying to control weed species that are difficult to kill, and which survive boom spraying, as spot spraying reduces the effects on clover production [39]. They are also excellent for application by herbicide wipers because of their superior translocation within plants, which also helps to minimize damage to pasture $[40,41,49,50]$.

\subsubsection{Acetolactate Synthase-Inhibitor (ALS-inhibitor) Herbicides}

ALS-inhibitor herbicides are effective against a wide range of weed species in pasture and arable crops [51-53]. These herbicides have become popular because of very low application rates, low mammalian toxicity and excellent herbicidal activity [54]. Flumetsulam and thifensulfuron are two ALS-inhibitor herbicides selective enough to be applied to New Zealand pastures and are used to 
manage Ranunculus spp. [55,56], and Rumex spp. [14]. Metsulfuron-methyl is another ALS-inhibitor herbicide used in pastures, because of its excellent translocation properties, but its lack of selectivity means that it is used as a spot application [39] or with wiper applications [41]. Boom spraying of this herbicide is not recommended as this will lead to the complete removal of clovers and suppression of ryegrass and will also affect the re-establishment of pasture species due to residues lasting up to three months within the soil depending on soil $\mathrm{pH}[57,58]$.

\subsubsection{Other Herbicides}

In New Zealand pastures, there is the occasional use of herbicides that are not auxinic or ALS-inhibitors for selective control of weeds. Fenoxaprop is an acetyl CoA carboxylase (ACCase) inhibitor and is used for selective control of Setaria pumila in pastures [59]. Bentazone is a photosystem II inhibitor (benzothiadiazinone group) which is used for control of weed seedlings in new pastures but can also be applied 1-5 days after MCPA to give good control of Ranunculus acris [38]. Glyphosate (5-enolpyruvylshikimate-3-phosphate (EPSP) synthase inhibitor) is a non-selective herbicide that is occasionally used in New Zealand pastures for spot application to control grasses, herbaceous plants including deep-rooted perennial weeds, and some shrub species [14,60]. Glyphosate is more important for pasture renovation in New Zealand as it leaves no residues [61]. The application of glyphosate for pasture renovation also provides a relatively weed-free environment for the drilling of seeds [62]. Glyphosate has also been used for wiper application to tall weeds within established pastures because of its ability to move into underground organs of perennial weeds [41,63].

\subsubsection{Herbicide Resistance in New Zealand Pastoral Weeds}

Herbicide resistance in weeds occurs in situations where herbicides with similar modes of action are applied for several years continuously [64]. Currently, there are 13 weed species that have evolved resistance to one or more herbicides in different New Zealand agricultural sectors [38,47,48,65-69]. Four weed species have so far become resistant to one or more herbicides in New Zealand pastures [38,70,71], with the first cases reported in the early $1980 \mathrm{~s}$ [41].

The frequent use of phenoxy herbicides 2,4-D, MCPA and MCPB, has led to biotypes of Carduus nutans and Carduus pycnocephalus L. that are resistant to this group of herbicides $[38,72,73]$. Biotypes of Ranunculus acris have also evolved resistance to MCPA [74]. Repeated application of phenoxy herbicides annually has promoted these cases of resistance, partly because of their effect on animal production if left unsprayed, and partly because there was a legal obligation to control Carduus nutans in some areas. More recently, Lusk et al. [56] reported resistance of Ranunculus acris to flumetsulam and thifensulfuron after about 20 years of applications of mainly flumetsulam to manage MCPA-resistant Ranunculus acris populations in pastures. Nassella neesiana is the other pasture weed species that has evolved herbicide resistance, in this case to dalapon, a lipid inhibitor, within one isolated population [75].

In order to prolong the useful lifetimes of the few herbicides that can be used in pastures, implementing sustainable weed control programs is important $[76,77]$. Several strategies have been developed for preventing evolution of herbicide-resistant weed species in New Zealand pastures [38]. Diversity in weed management methods is important for reducing the risk of herbicide resistance evolving in pasture weeds. For instance, it is recommended to alternate annually between MCPA in one year and flumetsulam in the following year for sustainable control of Ranunculus acris [78]. Another option is to apply herbicides with a different mode of action such as glyphosate using weed wipers or spot applications [41].

A related matter is the recent evolution of resistance to glyphosate in ryegrass species in some New Zealand vineyards [61,66], which has raised concerns regarding the spread of the resistance gene to ryegrass within pastures $[67,79]$. Perennial ryegrass is an obligate outcrossing species [80], and this could result in pollen from glyphosate-resistant plants being dispersed to neighboring plants. This could have some advantages if the ryegrass could then tolerate glyphosate, but it would also cause problems when pastures were sprayed out with glyphosate for cropping or pasture renewal. 
However, seeds produced from inadvertent crossing of glyphosate-resistant ryegrass with ryegrass plants in pastures may not be able to recruit within the pasture due to the competitive nature of swards grown in New Zealand.

\section{Agronomic Tactics for Pasture Weed Control}

Grazing management and the establishment of competitive and persistent pasture species are agronomic tactics that are commonly used to improve weed management in New Zealand pastures [11], making herbicide use less necessary. Grazing management can improve pastoral weed management by keeping pastures as dense as possible throughout the year, thus improving the plant competition which reduces weed establishment rates and population size [14,38]. Many studies have demonstrated the influence of grazing management on competition of pasture plants against weed establishment and growth. For instance, Silvertown and Smith [81] noted a significant impact of grazing management on reducing spring establishment of Cirsium vulgare in pastures. They showed that the rate of seedling establishment for Cirsium vulgare was increased in pastures where the swards were over-grazed. Similarly, Forcella and Wood [82] noted that over-grazing increased seedling survival, transition rate from rosette to flowering and seed production in Cirsium vulgare due to a reduction in competition from neighboring pasture plants.

The success of grazing management for weed management in pastures depends on grazing time, grazing intensity and pressure, animal stocking rates and the class of stock (e.g., sheep vs. goat) [83]. If grazing is used as a tactic for weed management, one should consider the time when the weed is most susceptible to livestock grazing [84]. For instance, Hartley et al. [85] noted that hard grazing of Critesion murinum (L.) Á.Löve in spring before flowering led to a reduction in the number of seeds per head and could eradicate this species from pastures after 3 years of sheep grazing. Although hard grazing in spring could be a powerful tactic for managing weeds through removing their flower heads and reducing seed production [83], increasing the level of grazing intensity in late summer and early autumn can provide an opportunity for new weeds to establish in pastures [14]. Harker et al. [86] noted that heavy grazing in summer weakened the regrowth of perennial grasses in pasture and as a result this led to an increase in the level of weed infestation. Schuster et al. [87] found winter cattle grazing resulted in a reduction in weed infestation, and the level of grazing intensity significantly affected the number of emerged weed seedlings, and the weed seed bank size. Espie [88] found that while high-intensity grazing increased establishment of Pilosella species, low-intensity spring-summer grazing significantly reduced the number of upright Pilosella species, but not prostrate ones.

The class of stock grazing pastures can influence the richness of weed species as the intensity of damage to weeds can vary between types of livestock due to different diet selection behavior [83]. For instance, goats are more likely than sheep or cattle to eat upright, spiny and woody weeds such as Rubus fruticosus [89], Ulex europaeus [90] and Juncus spp. [83]. Sheep can provide good control of Ranunculus acris [83] and Jacobaea vulgaris [91] in cattle grazed pastures where these weed species have dominated due to avoidance of them by cattle [14].

In addition to management of grazing, maximizing competition by pastoral species with weeds is another agronomic tactic that can be used for pastoral weed management [13]. Pasture species differ in their effectiveness for competing with weed species since they differ in growth forms and patterns and are sown at different densities [14]. Both grasses and legumes can be used to suppress weed seedling emergence and survival [92,93]. However, grass species such as Lolium perenne are more suppressive than legumes against weeds as they provide higher ground cover density than legumes [92], so can compete strongly with the seedlings of weeds [94,95].

It has been suggested that using a wider range of pastoral plant species could reduce weed invasion in pastures since less unexploited resources (i.e., moisture and nutrients) will remain for weeds when pastures are sown with more than two species [96]. Sanderson et al. [97] reported that the inclusion of diverse forage species in grass-legume mixtures reduced weed ingress simply because the greater herbage mass prevented weed invasion. Also, Tozer et al. [98] stated that the addition of 
forage herbs, Cichorium intybus L. or Plantago lanceolate L., in grass-legume mixtures reduced weed infestations in sheep and beef farms.

Theoretically, the results from the manipulation of plant competition studies suggest that including a high proportion of competitive plant species in pastoral mixtures would maximize weed management efficacy as the competitive plant species would suppress weed seedlings. However, in practice it is not simple as pastures often confront biotic (e.g., pests) and abiotic (e.g., drought stress) constraints that provide openings in swards for weeds to establish [99]. Also, preferential grazing by livestock of desirable pasture species can change the competitive balance of pasture plant mixtures in favor of weeds, causing an increase in weed ingress [100]. Thus, simply using competitive plant species as a single tactic may not guarantee sustainable weed management in pastures. However, combined agronomic strategies such as using competitive plant species with good grazing management are used routinely by skilled farmers, and will become increasingly important in areas where the evolution of herbicide resistance develops to the currently available herbicides for pastoral weeds in New Zealand [38].

\section{Biological Control of Weeds}

Biological control of weeds in New Zealand pastures has been extensively reviewed by Bourdôt et al. [14], so here we focus on recent research and developments. Biological weed control in New Zealand pastures is categorized into classical methods (e.g., using insects) and bioherbicides (i.e., pathogenic agents) [101]. For classical biological control, research projects have been undertaken for several New Zealand pastoral weeds, including Jacobaea vulgaris [102], Hypericum perforatum [103], Carduus nutans [104], Jacobaea vulgaris [105] and Cirsium arvense [106]. Unfortunately, most of the published results from this work only involve small-scale experimental studies prior to widespread release of organisms. There has seldom been rigorous evidence provided of the success of classical biological control of pastoral weeds in New Zealand following these initial assessments.

However, there are some reports claiming successful pastoral weed management using insects. For instance, it has been reported that the introduction of a beetle, Chrysolina hyperici Forster, has resulted in substantial biological control of Hypericum perforatum L.in New Zealand pastures [102]. It is also claimed that biological control has had a major effect on Jacobaea vulgaris and a moderate effect on Carduus nutans (Suckling, 2013). However, it is often not clear whether the suppression of weed populations is due to the biological control agents or other factors. Cripps et al. [107] evaluated the performance of Cirsium arvense under a combination of neighboring plant competition and the herbivorous agent, Cassida rubiginosa, and they found competition from neighboring pasture species was more important for Cirsium arvense suppression than the herbivory from the insect. Further studies are needed for other biological control agents released to date in order to provide rigorous evidence of whether the reported weed suppression is due to the biological agent.

Bourdôt et al. [14] reviewed several cases of bio-herbicide research for pastoral weed control in New Zealand prior to 2006, and the potential of other plant pathogenic agents for pastoral weed control in New Zealand has been further evaluated since then [108-110]. However, to date, none of these findings have resulted in commercially available, registered bio-herbicide products for a variety of reasons, including problems with formulation and efficacy. Although bio-herbicides might have the potential to assist with future weed management systems in New Zealand pastures, further research is needed to make them a viable option. Very few bio-herbicides have been successfully commercialized worldwide, and formulation is often the obstacle as it might take several years of study to develop a suitable formulation for bio-herbicides [111].

\section{Integrated Weed Management}

An "integrated weed management" approach has been strongly advocated for managing weeds [77,112]. With integrated weed management, a combination of chemical and non-chemical methods is employed to provide a better solution for weed control [113]. This can delay the adaptation of weeds to control 
methods such as the application of herbicides and evolution of resistance to herbicides within weed populations by reducing selection pressure [114].

In perennial pastures, an integrated weed management approach could consist of a combination of chemical methods (e.g., herbicide strategies), cultural methods (e.g., pasture and grazing management techniques), physical methods (e.g., mowing, or mechanical removal of plants surviving herbicides) and biological control methods. King et al. [115] illustrated this when they suggested the implementation of a range of physical and cultural control options such as manual or mechanical removal techniques and the application of herbicides (e.g., triclopyr and glyphosate) could provide the best control of Ulex europaeus in pastures. In another example, by using an optimization model, Chalak-Haghighi et al. [43] suggested a range of scenarios that could be used to manage Cirsium arvense in pastures. For instance, they showed that for a low density of Cirsium arvense (1-15 shoots $\left.\mathrm{m}^{-2}\right)$, the best strategy is a combination of the application of MCPA and intensified grazing but for a higher density of Cirsium arvense (15-40 shoots $\mathrm{m}^{-2}$ ), the best strategy is mowing in late summer plus chemical options and grazing management techniques.

These studies suggest that combining different weed management tactics and including both chemical and non-chemical approaches can offer an integrated approach which is cost effective for pastoral weed management. Integrated weed management also provides diversity which is a key factor for reducing the risk of evolution of herbicide-resistant weeds in pasture where there is a limited number of chemical options available [38]. These concepts are illustrated by strategies discussed by Harrington [116] and communicated to farmers in a variety of ways including using a website [78]. During the period of 1980-1995, numerous sites were found in New Zealand where the biennial thistle species Carduus nutans had developed resistance to the phenoxy herbicides MCPA, MCPB and 2,4-D due to annual applications of these herbicides for several decades. Herbicide options to deal with these weeds were to add low amounts of clopyralid to any of these phenoxy herbicides when applied, or to apply glyphosate or clopyralid to the thistles using a weed wiper after bolting but before flowering to prevent seeding. Pasture management techniques involved mainly keeping pasture competitive throughout the year to stop new plants germinating. As most of the seedlings establish in autumn after rainfall following periods of summer drought, strategies discussed by Harrington [116] were to improve the drought tolerance of pastures by adding species more tolerant of dryness than the commonly used Lolium perenne, such as Dactylis glomerata L. or Festuca arundinacea. Growing fodder crops over summer such as brassica crops and lucerne would reduce the grazing pressure on pastures in the remainder of the farm, making them more competitive through the autumn period. Goats will eat the bolting thistles more effectively than cattle or sheep, reducing seed production. Cattle leave more pasture following grazing than sheep, which helps keep pastures competitive against thistle seedlings. Some biological control is provided by Rhinocyllus conicus Froel., Trichosirocalus horridus Panzer and Urophora solstitialis Linnaeus Rhinocyllus conicus Froel., Trichosirocalus horridus Panzer and Urophora solstitialis Linnaeus [117]. In 2019, reports of phenoxy resistance in Carduus nutans are now seldom received.

\section{Conclusions and Future Directions}

Weeds can generally be prevented from causing a major impediment to production from New Zealand pastures due to their management by farmers. This includes the use of good pasture and grazing management techniques, effective utilization of selective herbicides that prevent domination by weeds while conserving the clover component of the swards, and with some assistance from biological control. Herbicides are used more extensively on farms where high returns per hectare can justify the costs involved, especially dairying but also animal production units based on fertile farmland where production is high. Lower profits are made from steep hill country properties. So, herbicides are often used much less, and more reliance is placed on the use of grazing management, including cross-grazing between cattle and sheep, and increased fencing to allow greater grazing pressure. The aerial application of fertilizers has occurred for many decades on this hill country to 
improve pasture competition against weeds, and herbicides such as 2,4-D can also occasionally be applied by airplane or helicopter to these hilly pastures when weed densities become too high.

However, changes in New Zealand farming systems can mean changes in weed control strategies. Consumer preferences for food produced without pesticides or minimal pesticides have created market forces that encourage a move to farming systems that use less or no herbicides. Research in New Zealand has shown that in the absence of herbicides on organic dairy farms, high pasture production can still be achieved by managing weeds using pasture and grazing management [118-120]. However, within such systems, there needs to be more tolerance by farmers of low weed densities within pastures, many of which are eaten by livestock and have some benefits [121].

Another New Zealand farming trend has been to grow more complex pasture mixes than simply a grass/legume mix. Cichorium intybus is often added to give a deeper rooting herb for summer production [122], but as this is an Asteraceae species, most phenoxy herbicides can no longer be used. Likewise, many swards are now being planted with Plantago lanceolata $\mathrm{L}$. included as recent research has shown this species will reduce nitrogen leaching into waterways due to reduced nitrogen content of animal urine [123]. This also greatly reduces the range of selective herbicides that can be used.

Over time, changes in weed flora can occur, towards species not well controlled by current herbicide methods. Grass weeds are always difficult to selectively remove from grass-based swards using herbicides. Critesion spp. are sharp-awned annual grasses which have caused problems for many decades in New Zealand sheep pastures [14]. Recently, another sharp-awned grass, Setaria pumila, has been aggressively invading high value dairy pastures [22], and some hill country pastures are now being invaded by Nassella spp. [17]. Other low producing grasses such as Agrostis spp. have always been difficult to remove from ryegrass pastures, especially in hill country where regrassing strategies are more difficult. Although some herbicide options are available for grass weeds, they are often not very successful.

Therefore, although herbicides can be used to control many weeds in simple ryegrass/clover pastures, research in New Zealand will need to continue refining non-herbicide control techniques to deal with weeds in more complex pastures swards, for organic farming systems, and to deal with weeds that are not easily controlled using current herbicides. There is also the potential for more use of herbicide application equipment that selectively wipes herbicides on tall weeds [41], or that can efficiently apply herbicide only to patches of weeds through various optical recognition technologies [124].

Author Contributions: Conceptualization, H.G. and K.C.H.; Writing—Original Draft Preparation, H.G.; Review and Editing, K.C.H.

Funding: This research received no external funding.

Conflicts of Interest: Authors declare no conflict of interest.

\section{References}

1. Tomlinson, I. Doubling food production to feed the 9 billion: A critical perspective on a key discourse of food security in the UK. J. Rural Stud. 2013, 29, 81-90. [CrossRef]

2. Rosegrant, M.W.; Fernandez, M.; Sinha, A.; Alder, J.; Ahammad, H.; De Fraiture, C.; Eickhour, B.; Fonseca, J.; Huang, J.; Koyama, O.; et al. Looking into the future for agriculture and AKST. In International Assessment of Agricultural Knowledge, Science and Technology for Development (IAASTD): Agriculture at a Crossroads, Global Report; McIntyre, B.D., Herren, H.R., Wakhungu, J., Watson, R.T., Eds.; Island Press: Washington, DC, USA, 2009; pp. 307-376.

3. Thornton, P.K. Livestock production: Recent trends, future prospects. Philos. Trans. R. Soc. Lond. B Biol. Sci. 2010, 365, 2853-2867. [CrossRef] [PubMed]

4. Anonymous. Environment Guide-Agriculture. 2018. Available online: http://www.environmentguide.org. nz/activities/agriculture/ (accessed on 20 May 2019).

5. Zimdahl, R.L. Weed-Crop Competition, a Review; International Plant Protection Center: Corvallis, OR, USA, 1980; p. 198. 
6. Anderson, W.P. Weed Science: Principles and Applications; West Publishing Co.: St. Paul, MN, USA, 1996; p. 338 .

7. Monaco, T.J.; Weller, S.C.; Ashton, F.M. Weed Science: Principles and Practices, 4th ed.; John Wiley and Sons, Inc.: New York, NY, USA, 2001.

8. Vencill, W.K. Herbicide Handbook; Weed Science Society of America: Lawrence, KS, USA, 2002; p. 493.

9. Kemp, P.D.; Matthew, C.; Lucas, R.J. Pasture species and cultivars. In New Zealand Pasture and Crop Science; White, J., Hodgson, J., Eds.; Oxford University Press: Melbourne, Australia, 2000.

10. Seefeldt, S.S.; Stephens, J.M.C.; Verkaaik, M.L.; Rahman, A. Quantifying the impact of a weed in a perennial ryegrass-white clover pasture. Weed Sci. 2005, 53, 113-120. [CrossRef]

11. Tozer, K.N.; Bourdot, G.W.; Edwards, G.R. What factors lead to poor pasture persistence and weed ingress? Proc. Int. Grassl. Conf. 2011, 15, 129-138.

12. Bourdot, G.W.; Saville, D.J. Estimating economic losses due to pasture weeds. N. Z. Plant Prot. J. 2002, 55, 106-110.

13. Eerens, J.P.J.; Rahman, A.; James, T.K. Optimising pasture production to minimise weed growth. Proc. N. Z. Grassl. Assoc. 2002, 64, 143-146.

14. Bourdôt, G.W.; Fowler, S.V.; Edwards, G.R.; Kriticos, D.J.; Kean, J.M.; Rahman, A.; Parsons, A.J. Pastoral weeds in New Zealand: Status and potential solutions. N. Z. J. Agric. Res. 2007, 50, 139-161. [CrossRef]

15. Popay, I.; Champion, P.; James, T. An Illustrated Guide to Common Weeds of New Zealand; New Zealand Plant Protection Society: Christchurch, New Zealand, 2010.

16. Champion, P.; James, T.K.; Popay, A.I.; Ford, K. An Illustrated Guide to Common Grasses, Sedges and Rushes of New Zealand; New Zealand Plant Protection Society: Christchurch, New Zealand, 2012; p. 182.

17. Saunders, J.T.; Greer, G.; Bourdôt, G.; Saunders, C.; James, T.; Rolando, C.; Monge, J.; Watt, M.S. The economic costs of weeds on productive land in New Zealand. Int. J. Agric. Sustain. 2017, 15, 380-392. [CrossRef]

18. Grice, A.C.; Campbell, S.D. Weeds in pasture ecosystems-symptom or disease? Trop. Grassl. 2000, 34, $264-270$.

19. Kelly, D.; Popay, A.I. Pasture production lost to unsprayed thistles at two sites. Proc. N. Z. Weed Pest Control Conf. 1985, 38, 115-118.

20. Wardle, D.A.; Nicholson, K.S.; Ahmed, M.; Rahman, A. Interference effects of the invasive plant Carduus nutans L. against the nitrogen fixation ability of Trifolium repens L. Plant Soil 1994, 163, 287-297. [CrossRef]

21. Haggar, R.J.; Oswald, A.K.; Richardson, W.G. A review of the impact and control of creeping thistle (Cirsium arvense L.) in grassland. Crop Prot. 1986, 5, 73-76. [CrossRef]

22. James, T.K.; Tozer, K.N.; Rahman, A. Yellow bristle grass: A recent weed incursion in Waikato dairy pastures. Proc. N. Z. Grassl. Assoc. 2009, 71, 39-42.

23. Duke, S.O. Proving allelopathy in crop-weed interactions. Weed Sci. 2015, 63, 121-132. [CrossRef]

24. Fernandez, C.; Monnier, Y.; Santonja, M.; Gallet, C.; Weston, L.A.; Prévosto, B.; Saunier, A.; Baldy, V.; Bousquet-Mélou, A. The impact of competition and allelopathy on the trade-off between plant defense and growth in two contrasting tree species. Front. Plant Sci. 2016, 7, 594. [CrossRef]

25. Wardle, D.A. Allelopathy in the New Zealand grassland/pasture ecosystem. N. Z. J. Exp. Agric. 1987, 15, 243-255. [CrossRef]

26. Smith, A.E. Potential allelopathic influence of certain pasture weeds. Crop Prot. 1990, 9, 410-414. [CrossRef]

27. Ahmed, M.; Wardle, D.A. Allelopathic potential of vegetative and flowering ragwort (Senecio jacobaea L.) plants against associated pasture species. Plant Soil 1994, 164, 61-68. [CrossRef]

28. Wardle, D.A.; Nicholson, K.S.; Rahman, A. Influence of plant age on the allelopathic potential of nodding thistle (Carduus nutans L.) against pasture grasses and legumes. Weed Res. 1993, 33, 69-78. [CrossRef]

29. Smith, A.E.; Martin, L.D. Weed management systems for pastures and hay crops. In Handbook of Weed Management Systems; Smith, A.E., Ed.; Marcel Dekker: New York, NY, USA, 1995; pp. 477-518.

30. Bourdôt, G.W.; Lamoureaux, S. Giant buttercup (Ranunculus acris L.) management in dairy pastures-Current problems and future solutions. Proc. Conf. N. Z. Grassl. Assoc. 2002, 64, 61-65.

31. Cortinovis, C.; Caloni, F. Alkaloid containing plants poisonous to cattle and horses in Europe. Toxins 2015, 7, 5301-5307. [CrossRef]

32. Dowling, P.M.; Michalk, D.L.; Sindel, B.M. Weed Management in Pasture Systems; R.G. and F.J. Richardson: Melbourne, Australia, 2000; pp. 307-328.

33. Matthews, P.N.P.; Harrington, K.C.; Hampton, J.G. New Zealand pasture and crop science. In New Zealand Pasture and Crop Science; White, J., Hodgson, J., Eds.; Oxford University Press: Oxford, UK, 2000; pp. 153-174. 
34. Williams, R.D. Crop Protection Handbook—Grass and Clover Swards; British Crop Protection Council: Croydon, UK, 1984; p. 105.

35. Hartley, M.J.; James, T.K. Cost benefit of Californian thistle control in pasture. Proc. N. Z. Weed Pest Control Conf. 1979, 32, 245-249.

36. Matthews, L.J. Pasture weeds of New Zealand. In Biology and Ecology of Weeds; Holzner, W., Numata, M., Eds.; Springer Netherlands: Dordrecht, The Netherlands, 1982; pp. 387-394. [CrossRef]

37. Matthews, P.N.P.; Harrington, K.C.; Hampton, J.G. Management of grazing systems. In New Zealand Pasture and Crop Science; White, J., Hodgson, J., Eds.; Oxford University Press: Melbourne, Australia, 2000; pp. 153-174.

38. Harrington, K.C.; Ghanizadeh, H. Management and mitigation strategies for herbicide-resistant weeds in New Zealand. In Agricultural Research Updates; Gorawala, P., Mandhatri, S., Eds.; Nova Publishers: New York, NY, USA, 2016; Volume 13, pp. 1-12.

39. Harrington, K.C.; Ghanizadeh, H.; Moyo, C.; Kemp, P.D.; Eerens, J.P.J. Pasture damage from spot-sprayed herbicides. N. Z. Plant Prot. J. 2017, 70, 179-185. [CrossRef]

40. Moyo, C.; Harrington, K.C.; Ghanizadeh, H.; Kemp, P.D.; Eerens, J.P.J. Spectrophotometric technique for measuring herbicide deposition from wiper applicators. N. Z. J. Agric. Res. 2016, 59, 412-421. [CrossRef]

41. Harrington, K.C.; Ghanizadeh, H. Herbicide application using wiper applicators-A review. Crop Prot. 2017, 102, 56-62. [CrossRef]

42. Thompson, A.; Saunders, A. A comparison of 2,4-D and MCPA, alone and in combination, for the control of ragwort. Proc. N. Z. Weed Pest Control Conf. 1984, 37, 33-36.

43. Chalak-Haghighi, M.; Van Ierland, E.C.; Bourdôt, G.W.; Leathwick, D. Management strategies for an invasive weed: A dynamic programming approach for Californian thistle in New Zealand. N. Z. J. Agric. Res. 2008, 51, 409-424. [CrossRef]

44. Tuckett, A.J. Giant buttercup. Proc. N. Z. Weed Pest Control Conf. 1961, 14, 124-126.

45. Popay, A.I.; Thompson, A. Nodding thistle: Its growth and control. N. Z. J. Agric. 1980, 141, $63-69$.

46. Honore, E.N.; Rahman, A.; Dyson, C.B. Effect of winter application of phenoxy herbicides on white clover and pasture production. Proc. N. Z. Weed Pest Control Conf. 1980, 33, 55-58.

47. Ghanizadeh, H.; Harrington, K.C.; James, T.K.; Woolley, D.J. A quick test using seeds for detecting dicamba resistance in fathen (Chenopodium album). Aust. J. Crop Sci. 2015, 9, 337-343.

48. Ghanizadeh, H.; Harrington, K.C. Fitness costs associated with multiple resistance to dicamba and atrazine in Chenopodium album. Planta 2019, 249, 787-797. [CrossRef]

49. Moyo, C.; Harrington, K.C.; Kemp, P.D.; Eerens, J.P.J. Wiper application of herbicides to Californian thistle. N. Z. Plant Protect. J. 2006, 59, 361.

50. Harrington, K.C.; Ghanizadeh, H.; Moyo, C.; Kemp, P.D.; Eerens, J.P.J. Are root exudation or rainfall on treated plants likely causes of pasture damage after wiper application of herbicides? Proc. Aust. Weed Conf. 2016, 20, 72-75.

51. Whitcomb, C.E. An introduction to ALS-inhibiting herbicides. Toxicol. Ind. Health 1999, 15, $231-239$. [CrossRef]

52. Dekker, J.; Duke, S.O. Herbicide-resistant field crops. In Advances in Agronomy; Sparks, D.L., Ed.; Elsevier Academic Press Inc.: San Diego, CA, USA, 1995; Volume 54, pp. 69-116.

53. Forouzesh, A.; Zand, E.; Soufizadeh, S.; Samadi Foroushani, S. Classification of herbicides according to chemical family for weed resistance management strategies-An update. Weed Res. 2015, 55, 334-358. [CrossRef]

54. Blair, A.M.; Martin, T.D. A review of the activity, fate and mode of action of sulfonylurea herbicides. Pestic. Sci. 1988, 22, 195-219. [CrossRef]

55. Harris, B.M.; Husband, B.M. Flumetsulam for control of giant buttercup in pasture. Proc. N. Z. Plant Prot. Conf. 1997, 50, 472-476.

56. Lusk, C.S.; Hurrell, G.A.; Harrington, K.C.; Bourdot, G.W.; Saville, D.J. Resistance of Ranunculus acris to flumetsulam, thifensulfuron-methyl and MCPA in New Zealand dairy pastures. N. Z. J. Agric. Res. 2015, 58, 271-280. [CrossRef]

57. James, T.K.; Rahman, A.; Cornwell, M.J. Pasture tolerance to the herbicide metsulfuron-methyl. Proc. N. Z. Plant Prot. Conf. 1999, 52, 240-244.

58. Sabadie, J. Chemical acidic hydrolysis of metsulfuron methyl. Weed Res. 1990, 30, 413-419. [CrossRef] 
59. James, T.K.; Rahman, A.; Dowsett, C.A.; Trolove, M.R. Fenoxaprop for control of yellow bristle grass in pasture and its efficacy on other $C_{4}$ grasses. N. Z. Plant Prot. J. 2013, 66, 118-123.

60. Ghanizadeh, H.; Harrington, K.C.; James, T.K.; Woolley, D.J. Quick tests for detecting glyphosate-resistant Italian and perennial ryegrass. N. Z. J. Agric. Res. 2015, 58, 108-120. [CrossRef]

61. Ghanizadeh, H.; Harrington, K.C.; James, T.K.; Woolley, D.J. Confirmation of glyphosate resistance in two species of ryegrass from New Zealand vineyards. N. Z. Plant Prot. J. 2013, 66, 89-93.

62. Sawada, M.; Kunezaki, K.; Januma, T. Renovation of deteriorated pasture by surface sowing renovation of pasture with glyphosate herbicide and burning. Proc. Int. Grassl. Conf. 1985, 15, 567-568.

63. Ghanizadeh, H.; Harrington, K.C. Non-target site mechanisms of resistance to herbicides. Crit. Rev. Plant Sci. 2017, 36, 24-34. [CrossRef]

64. Ghanizadeh, H.; Harrington, K.C. Perspectives on non-target site mechanisms of herbicide resistance in weedy plant species using evolutionary physiology. AoB Plants 2017, 9, plx035. [CrossRef]

65. Ghanizadeh, H.; Harrington, K.C.; James, T.K. Glyphosate-resistant Lolium multiflorum and Lolium perenne populations from New Zealand are also resistant to glufosinate and amitrole. Crop Prot. 2015, 78, 1-4. [CrossRef]

66. Ghanizadeh, H.; Harrington, K.C.; James, T.K. Glyphosate-resistant population of Lolium perenne loses resistance at winter temperatures. N. Z. J. Agric. Res. 2015, 58, 423-431. [CrossRef]

67. Ghanizadeh, H.; Harrington, K.C. Restricted glyphosate translocation in Lolium multiflorum is controlled by a single incomplete dominant nuclear gene. N. Z. J. Crop Hortic. Sci. 2018, 46, 346-353. [CrossRef]

68. Ghanizadeh, H.; Harrington, K.C.; Mesarich, C.H. The target site mutation Ile-2041-Asn is associated with resistance to ACCase-inhibiting herbicides in Lolium multiflorum. N. Z. J. Agric. Res. 2019. [CrossRef]

69. Ghanizadeh, H.; Harrington, K.C.; James, T.K. A comparison of dicamba absorption, translocation and metabolism in Chenopodium album populations resistant and susceptible to dicamba. Crop Prot. 2018, 110, 112-116. [CrossRef]

70. Ghanizadeh, H.; Harrington, K.C.; James, T.K.; Woolley, D.J.; Ellison, N.W. Restricted herbicide translocation was found in two glyphosate-resistant Italian ryegrass (Lolium multiflorum Lam.) populations from New Zealand. J. Agric. Sci. Technol. 2016, 18, 1041-1051.

71. Ghanizadeh, H.; Harrington, K.C. Cross-resistance to auxinic herbicides in dicamba-resistant Chenopodium album. N. Z. J. Agric. Res. 2017, 60, 45-53. [CrossRef]

72. Harrington, K.C.; Hewage, N. Resistance of slender winged thistle to MCPA. Proc. N. Z. Plant Prot. Conf. 1997, 50, 538.

73. Harrington, K.C.; Woolley, D.J. Investigations of how phenoxy-resistant Carduus nutans biotypes survive herbicide spraying. N. Z. J. Agric. Res. 2006, 49, 465-474. [CrossRef]

74. Bourdôt, G.W.; Hurrell, G.A. Differential tolerance of MCPA among giant buttercup (Ranunculus acris) biotypes in Takaka, Golden Bay. Proc. N. Z. Weed Pest Control Conf. 1988, 41, 231-234.

75. Hartley, M.J. Dalapon resistant individuals in a susceptible population of Chilean needle grass. Proc. N. Z. Plant Prot. Conf. 1994, 47, 75-79.

76. Ghanizadeh, H.; Harrington, K.C.; James, T.K. Glyphosate-resistant Italian ryegrass and perennial ryegrass in New Zealand-A review. N. Z. Plant Prot. J. 2016, 69, 246-251.

77. Harrington, K.C.; James, T.K.; Parker, M.D.; Ghanizadeh, H. Strategies to manage the evolution of glyphosate resistance in New Zealand. N. Z. Plant Prot. J. 2016, 69, 252-257.

78. Harrington, K.C. Managing Phenoxy Resistance in Pasture Weeds. 2014. Available online: http://resistance. nzpps.org/index.php?p=herbicides/phenoxy. (accessed on 20 May 2019).

79. Ghanizadeh, H.; Harrington, K.C.; James, T.K. Genetic inheritance of restricted herbicide translocation in a glyphosate-resistant Lolium perenne population. N. Z. J. Agric. Res. 2016, 59, 269-279. [CrossRef]

80. McCraw, J.M.; Spoor, W. Self-incompatibility in Lolium species 2 Lolium perenne. Heredity 1983, 50, $29-33$. [CrossRef]

81. Silvertown, J.; Smith, B. Germination and population structure of spear thistle (Cirsium vulgare) in relation to experimentally controlled sheep grazing. Oecologia 1989, 81, 369-373. [CrossRef]

82. Forcella, F.; Wood, H. Demography and control of Cirsium vulgare (Savi) Ten. in relation to grazing. Weed Res. 1986, 26, 199-206. [CrossRef]

83. Popay, I.; Field, R. Grazing animals as weed control agents. Weed Technol. 1996, 10, 217-231. [CrossRef]

84. Brock, J.H. Livestock: Biological control in brush/weed management programs. Rangelands 1988, 10, 32-34. 
85. Hartley, M.J.; Atkinson, G.C.; Bimler, K.H.; James, T.K.; Popay, A.I. Control of barley grass by grazing management. Proc. N. Z. Weed Pest Control Conf. 1978, 31, 198-202.

86. Harker, K.N.; Vern, S.B.; David, S.C.; Naeth, M.A.; Stevenson, F.C. Grazing intensity effects on weed populations in annual and perennial pasture systems. Weed Sci. 2000, 48, 231-238. [CrossRef]

87. Schuster, M.Z.; Pelissari, A.; de Moraes, A.; Harrison, S.K.; Sulc, R.M.; Lustosa, S.B.C.; Anghinoni, I.; Carvalho, P.C.F. Grazing intensities affect weed seedling emergence and the seed bank in an integrated crop-livestock system. Agric. Ecosyst. Environ. 2016, 232, 232-239. [CrossRef]

88. Espie, P.R. Integrated pastoral management strategies for Hieracium control. Proc. N. Z. Grassl. Assoc. 1994, 56, 243-247.

89. Peirce, J. Using goats to control weeds. J. Dep. Agric. West. Aust. 1991, 32, 83-87.

90. Clark, D.A.; Lambert, M.G.; Rolston, M.P.; Dymock, N. Diet selection by goats and sheep on hill country. Proc. N. Z. Soc. Anim. Prod. 1982, 42, 155-157.

91. Betteridge, K.; Costall, D.A.; Hutching, S.M.; Devantier, B.P. Ragwort (Senecio jacobaea) control by sheep in a hill country bull beef system. Proc. N. Z. Plant Prot. Conf. 1994, 47, 53-57.

92. Wardle, D.A.; Nicholson, K.S.; Ahmed, M.; Rahman, A. Influence of pasture forage species on seedling emergence, growth and development of Carduus nutans. J. Appl. Ecol. 1995, 32, 225-233. [CrossRef]

93. Wardle, D.A.; Nicholson, K.S.; Rahman, A. Influence of pasture grass and legume swards on seedling emergence and growth of Carduus nutans L. and Cirsium vulgare L. Weed Res. 1992, 32, 119-128. [CrossRef]

94. Hartley, M.J.; Thai, P.H. Effect of pasture species and grazing on survival of seedling gorse. Proc. N. Z. Weed Pest Control Conf. 1979, 32, 297-302.

95. Ivens, G.W.; Mlowe, F. Response of seedling gorse to fertilisers. Proc. N. Z. Weed Pest Control Conf. 1983, $36,52-55$.

96. Kennedy, T.A.; Naeem, S.; Howe, K.M.; Knops, J.M.H.; Tilman, D.; Reich, P. Biodiversity as a barrier to ecological invasion. Nature 2002, 417, 636-638. [CrossRef]

97. Sanderson, M.A.; Soder, K.J.; Muller, L.D.; Klement, K.D.; Skinner, R.H.; Goslee, S.C. Forage mixture productivity and botanical composition in pastures grazed by dairy cattle. Agron. J. 2005, 97, 1465-1471. [CrossRef]

98. Tozer, K.N.; Barker, G.M.; Cameron, C.A.; Wilson, D.; Loick, N. Effects of including forage herbs in grass-legume mixtures on persistence of intensively managed pastures sampled across three age categories and five regions. N. Z. J. Agric. Res. 2016, 59, 250-268. [CrossRef]

99. Peltzer, D.A.; Wilson, S.D. Competition and Environmental Stress in Temperate Grasslands; CABI: Wallingford, UK, 2001; pp. 193-212. [CrossRef]

100. Sindel, B.M. Management of Weeds in Pasture Systems; Food Products Press: Binghamton, NY, USA, 2006; pp. 771-790.

101. Fowler, S.V.; Syrett, P.; Hill, R.L. Success and safety in the biological control of environmental weeds in New Zealand. Austral Ecol. 2000, 25, 553-562. [CrossRef]

102. Fowler, S.V.; Gourlay, A.H.; Hill, R. Biological control of ragwort in the New Zealand dairy sector: An ex-post economic analysis. N. Z. J. Agric. Res. 2016, 59, 205-215. [CrossRef]

103. Groenteman, R.; Fowler, S.V.; Sullivan, J.J. St. John's wort beetles would not have been introduced to New Zealand now: A retrospective host range test of New Zealand's most successful weed biocontrol agents. Biol. Control 2011, 57, 50-58. [CrossRef]

104. Groenteman, R.; Kelly, D.; Fowler, S.V.; Bourdôt, G.W. Interactions between nodding thistle seed predators. N. Z. Plant Prot. 2007, 60, 152-157.

105. McLaren, D.A.; Cullen, J.M.; Morley, T.B.; Ireson, J.E.; Snell, K.A.; Gourlay, A.H.; Sagliocco, J.L. Host specificity and impacts of Platyptilia isodactyla (Lepidoptera: Pterophoridae), a biological control agent for Jacobaea vulgaris (Asteraceae) in Australia and New Zealand. Proc. Int. Symp. Biol. Control Weeds 2013, 13, 389-399.

106. Hayes, L.M. The Biological Control of Weeds Book-A New Zealand Guide. 2007. Available online: http: //www.landcareresearch.co.nz/publications/books/biocontrol-of-weeds-book (accessed on 25 August 2017).

107. Cripps, M.G.; Edwards, G.R.; Bourdôt, G.W.; Saville, D.J.; Hinz, H.L.; Fowler, S.V. Effects of pasture competition and specialist herbivory on the performance of Cirsium arvense. Biocontrol Sci. Technol. 2010, 20, 641-656. [CrossRef]

108. Bailey, K.; Derby, J.A.; Bourdot, G.; Skipp, B.; Cripps, M.; Hurrell, G.; Saville, D.; Noble, A. Plectosphaerella cucumerina as a bioherbicide for Cirsium arvense: Proof of concept. Biocontrol 2017, 62, 693-704. [CrossRef] 
109. Smith, B.; Casonato, S.G.; Noble, A.; Bourdot, G. Californian thistle and its variable response to the biological control agent, Sclerotinia sclerotiorum. N. Z. Plant Prot. 2016, 69, 258-262.

110. Skipp, R.A.; Bourdot, G.W.; Hurrell, G.A.; Chen, L.Y.; Wilson, D.J.; Saville, D.J. Verticillium dahliae and other pathogenic fungi in Cirsium arvense from New Zealand pastures: Occurrence, pathogenicity and biological control potential. N. Z. J. Agric. Res. 2013, 56, 1-21. [CrossRef]

111. Ash, G.J. The science, art and business of successful bioherbicides. Biol. Control 2010, 52, 230-240. [CrossRef]

112. Buhler, D.D. 50th Anniversary-Invited Article: Challenges and opportunities for integrated weed management. Weed Sci. 2002, 50, 273-280. [CrossRef]

113. Hartzler, R.G.; Buhler, D.D. Ecological Management of Agricultural Weeds. In Ecologically Based Integrated Pest Management; Koul, O., Cuperus, G.W., Eds.; CABI: Wallingford, UK, 2007; pp. 37-55.

114. Beckie, H.J. Herbicide-resistant weeds: Management tactics and practices. Weed Technol 2006, $20,793-814$. [CrossRef]

115. King, S.; Drlik, T.; Simon, L.; Quarles, W. Integrated weed management of gorse. IPM Pract. 1996, 18, 1-9.

116. Harrington, K.C. Herbicide management and thistle control-How to avoid resistance. Plant Prot. Q. 1996, 11, 273-275.

117. Suckling, D.M. Benefits from biological control of weeds in New Zealand range from negligible to massive: A retrospective analysis. Biol. Control 2013, 66, 27-32. [CrossRef]

118. Harrington, K.C.; Osborne, M.A.; Kemp, P.D. Weed cover unaffected after converting a dairy farm to organic production. N. Z. Plant Prot. 2008, 61, 116-120.

119. Harrington, K.C.; Osborne, M.A.; Kemp, P.D. Effect of 10 years of organic dairy farming on weed populations. Proc. Australas. Weeds Conf. 2012, 18, 159-162.

120. Harrington, K.C.; Kemp, P.D.; Horne, D.J.; He, X.Z. Weed population dynamics for contrasting organic pasture establishment techniques. N. Z. Plant Prot. 2013, 66, 110-117.

121. Harrington, K.C.; Thatcher, A.; Kemp, P.D. Mineral composition and nutritive value of some common pasture weeds. N. Z. Plant Prot. 2006, 59, 261-265.

122. Lewis, C.D.; Ho, C.K.M.; Jacobs, J.L.; Malcolm, B. Benefits and costs of grazing various proportions of perennial ryegrass and chicory for dairy production. Anim. Prod. Sci. 2018, 58, 1423-1431. [CrossRef]

123. Dodd, M.; Dalley, D.; Wims, C.; Elliott, D.; Griffin, A. A comparison of temperate pasture species mixtures selected to increase dairy cow production and reduce urinary nitrogen excretion. N. Z. J. Agric. Res. 2019, 62, 504-527. [CrossRef]

124. Gonzalez-de-Soto, M.; Emmi, L.; Perez-Ruiz, M.; Aguera, J.; Gonzalez-de-Santos, P. Autonomous systems for precise spraying-Evaluation of a robotised patch sprayer. Biosyst. Eng. 2016, 146, 165-182. [CrossRef] 